Article

\title{
Estimating Willingness to Pay for a Future Recreational Park Atop the Current Jakuševec Landfill in Zagreb, Croatia
}

\author{
Marija Opačak *(i) and Erda Wang * \\ Institute of Tourism and Environment Management, School of Economics and Management, Dalian University \\ of Technology, Dalian 116023, Liaoning, China \\ * Correspondence: o.marija@gmail.com (M.O.); edwang@dlut.edu.cn (E.W.)
}

Received: 12 September 2019; Accepted: 27 October 2019; Published: 30 October 2019

check for updates

\begin{abstract}
The main purpose of this study is to investigate the economic value potentially accrued by a prospective city park, which is planned to be built as a result of strategic land reclamation of a current landfill in Croatia, based on parkgoers' marginal willingness to pay. The idea of this land transformation is inspired by recent debate on the issue of how to address air quality and other environmental concerns over the disposal of the landfill site in the city. Like any other nonmarket valuation studies, choosing a proper survey method is a critical step for a successful economic valuation study. We adopted a double bounded dichotomous choice contingent valuation method in survey design and data collection, followed by parameter estimation using the logit model. The study reveals-(1) the support of 70\% of respondents was estimated; (2) as much as $96 \%$ of the respondents are willing to visit the park being presented to the respondents along with the survey questionnaire. The economic valuation indicates that the city residents are willing to pay $€ 3.63$ per person for the park's entrance fees, which can be translated into an aggregate of $€ 2,867,762$. By referring this value information to the park budget, we may persuade policy makers to commit to a transformation of the current landfill.
\end{abstract}

Keywords: contingent valuation method; double bounded dichotomous choice; willingness to pay; prospective city park; landfill

\section{Introduction}

Waste management sites such as landfills constitute a challenging problem facing city planners and policy-makers, for example in India [1,2], Vietnam [3], Sri Lanka [4], Australia [5], Germany [6], Japan [7], South Africa [8]. This challenge is related to several constraints, such as land space used for waste disposal and land reuse planning. Although there are multiple ways to manage land reuse, including deep burying, incineration, and land reconstruction, the key is to find the best land use alternative. It is crucial for the decision makers to assess the economic value to be potentially accrued either by the recovered resources or by the potential consumers who are directly affected by the land recovery strategies to ensure an efficient utilization of land recovery. However, considering that the market price for land reuses is commonly not available, the economic valuation of the reused land remains a complicated problem.

Urban parks are a valuable municipal source of and a key element for city sustainability, as they are able to facilitate proper land resource allocation for citizens so as to meet their recreational demands and play other social functions as well [9]. It has been proven that staying in urban greenery areas, like parks and forests, has positive and restorative effects on people's mood, peacefulness, concentration and stress release [10-14]. Urban parks contribute to the beautification of the city and have positive 
effects on environmental quality, including air freshness, carbon sequestration, water purity, as well as biodiversity. They thus improve city dwellers' overall quality of life in areas including physical health, social cohesion, tourism and consequently employment and revenues [15-19]. Furthermore, green spaces can act as leisure, sport, and recreational resources, reducing criminal and anti-social behavior as well as cutting down on obesity, since such spaces encourage physical fitness and exercise [20-23].

The closure of the current Jakuševec landfill was announced years ago and has been spurring on residents' dissatisfaction ever since, in particular the dissatisfaction of residents living in the immediate vicinity of the site. The management of the landfill, orchestrated by a city-owned company named ZGOS Ltd., carried out landfill remediation in 2003 and suggested December 31st, 2018 as the starting date for waste disposal cessation processes [24]. The Jakuševec-Prudinec landfill was established in 1965 and has gradually led to significant negative environmental impacts on its surrounding regions. Statistical surveys indicate that just up to the beginning of the 1990s, the landfill has occupied and polluted almost one million $\mathrm{m}^{3}$ of soil (soil material) and seriously jeopardized the quality of groundwater intended for drinking [25]. The groundwater pollution line has been spreading eastward, particularly in times of changing hydrodynamic conditions in the aquifer, which further increases concern among the citizens.

This is one of the seldom case studies in developing and small countries such as Croatia that supports brownfield regeneration, a new sustainable urban development planning method which functions by proposing a land use transformation based on a nonmarket valuation method. To this end, this study investigates individuals' willingness to pay (WTP) for landfill reuse in Croatia. Similar to Kountouris, Nakic and Sauer [26], we use specific timing to collect data. The suggestions we make based on research results should be of interest to researchers and policy-makers looking for a way to introduce parks to be created from the current landfill site. It should be highlighted that this study effort is not a common practice in this part of Europe, where people have a certain measure of distrust and fear toward certain types of government policies. Basically, the more trash that is piled up in the area, the more landfills are needed. Fortunately, they can also be converted into useful sites at the end of their functional life since landfills are conveniently located near major transportation routes and other major infrastructure in urban areas. In such a situation, alternative landfill conversions are possible, including but not limited to building parks, solar panels, residential buildings, malls, golf courses, dirt BMX bike tracks or combined development. For the time being, policy-makers are suggested to organize environmental education programs [27] and make extensive improvements in facilities for higher satisfaction of visitors [28]. Numerous examples demonstrate successful conversions of old landfills into recreational parks, such as-Flushing Meadows (New York, USA), Mt. Trashmore (Virginia, USA), Freshkills Park (New York, USA), Cesar Chavez Park (Berkley, USA), Sai Tso Wan Recreation Ground (Hong Kong), Pulau Semaku (Singapore), Port Sunlight River Park (Birkenhead, UK) and Hiriya Park (Tel-Aviv, Israel) and so forth. Thus, it seems that the option of building a recreational park after closing an old landfill could prove to be a promising measure, based on previous research literature on the redevelopment potentials of landfills [29-32] and the making of urban green space strategies [19,33].

According to Latinopoulos, Mallios and Latinopoulos [34], survey data may be considered a form of public investment at the early stage of planning, which is likely to increase public acceptance of the proposed projects. Lindsey and Knaap [35] argue that proper valuation of urban parks' services serves as the foundation for regulatory decisions. In addition, information obtained from contingent valuation can be used as a starting point for different analyses, including land-use planning, zoning boards' actions and conservation policies, particularly based on protest responses [36-38].

The contingent valuation method (CVM) is a survey technique that constructs a hypothetical market to measure willingness to pay or willingness to accept (WTA) compensation for different levels of non-marketed natural and environmental resources [39]. The method involves in-person interviews to clarify any possible puzzlements on the spot. Contingent valuation informs respondents about the tradeoffs they are facing; therefore, CVM is efficient in measuring (1) use value of a change in 
environmental quality prior to the policy being implemented and (2) non-use or passive use values such as the benefits the general public receive from the existence of unique natural environments. To eliminate hypothetical bias in eliciting accurate economic values, a survey method needs to be carefully designed and include three key components-(1) resource description, (2) means of payment and (3) the elicitation procedure.

Other researchers use CVM to estimate visitors' WTP with respect to changes in the landscape, for instance, Faizan, Sasekumar and Chenayah [40] on WTP by local tourists for an improved coral reef management scenario; Getzner and Švajda [41] on ascertaining the preferences and the perception of visitors to the Tatra National Park and its landscape, Iasha et al. [42] on estimating visitors' WTP for ecotourism in Puncak Lawang Park, Majumdar et al. [17] on estimating tourists' WTP for urban forests, Olorunfemi [43] on WTP for improved environmental quality among residents living in close proximity to landfills in Lagos Metropolis, Piriyapada and Wang [44] on modeling WTP for coastal tourism resource protection in Ko Chang Marine National Park, Wang and Jia [45] on tourists' willingness to pay for biodiversity conservation and environment protection in Dalai Lake Protected Area. While there are still research gaps from developing countries compared to developed ones [46], this study aims to assist in filling in those gaps. To this date, there are no plans for future reuse of landfill sites in Croatia and the region.

This paper is organized as follows-Section 1 gives a literature review on urban parks and CVM application in nonmarket valuation; Section 2 presents the studied area and the research methodology; Section 3 reports the results and discussion; while Section 4 provides a summary and conclusion.

\section{Material and Methods}

\subsection{Study Area}

The Jakuševec-Prudinec landfill is a municipal, non-hazardous waste site located in the eastern part of the city of Zagreb, on the right bank of the Sava River (Figures 1 and 2). It is the largest landfill in Croatia and among the largest in this part of Europe, with an area of 54 acres, $1365 \mathrm{~m}$ in length and $390 \mathrm{~m}$ in width [47]. Its most prominent environmental impact is on groundwater since it is situated on the aquifer, which is the basis of water supply for Zagreb. It is only $400 \mathrm{~m}$ away from Jakuševec residential area (to the west) and $5 \mathrm{~km}$ away from the city center [25]. The landfill stretches in the northwest-southeast direction, along the embankment of the Sava River, separated by a local road. The terrain is mostly flat with an elevation of $100 \mathrm{~m}$. The climate is temperate, continental type and rainfall is distributed almost evenly throughout the year. In 1965 the uncontrolled disposal of waste in the area of the landfill began, reaching $10 \mathrm{~m}$ in height and 80 hectares of the land area by 1995. Due to a neglect of this problem, the landfill became the largest unmanaged landfill in southeastern Europe.

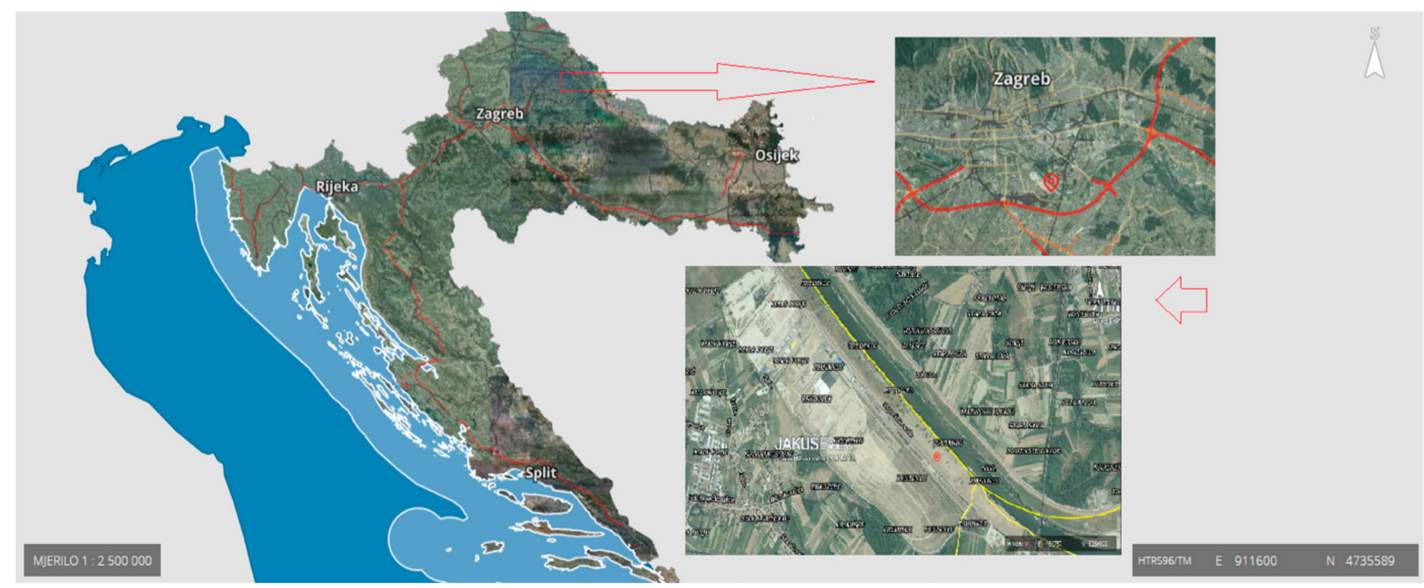

Figure 1. Study site location and the layout of Zagreb. Source: Geoportal of the State Geodetic Administration of the Republic of Croatia, 2018. 


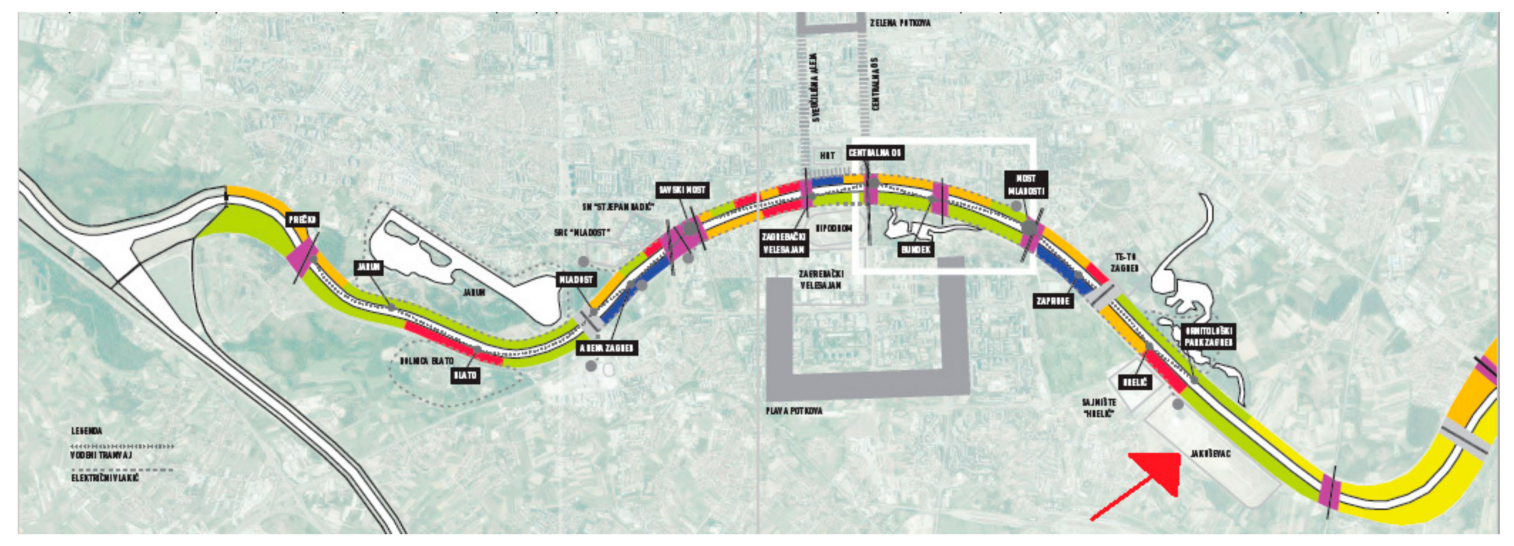

Figure 2. Study area within the Zagreb on Sava concept. Source: Zagreb na Savi Workshop, 2014. http://zagrebnasavi.hr/wp-content/uploads/2014/02/Radionica\%20Zagreb\%20na\%20Savi.pdf

According to the Spatial Plan and the Waste Management Plan of the City of Zagreb, the Jakuševec-Prudinec landfill will be converted into a green area. Therefore, this paper deals with a potential solution after closure of the landfill, that is, building a recreational park. A survey has been conducted to assess citizens' willingness to pay for the future recreational park. According to Latinopoulos, Mallios and Latinopoulos [34], using survey data is likely to improve the public acceptance of proposed projects because it may be considered as a form of public involvement at an early stage of planning.

\subsection{Survey Instrument}

A CVM survey was conducted among 391 citizens of the city of Zagreb between February 2017 and March 2019. The questionnaire format to collect responses was the dichotomous choice contingent valuation method (DCCVM) or referendum questionnaire. The introduction part, where the research and its purpose were introduced, was followed by three sections-(1) socio-demographic data; (2) environmental concerns about the landfill site; (3) willingness to pay. To obtain honest and accurate information, as well as to maximize response rates, respondents were informed that their information is completely confidential and for academic purposes, as it will be used for academic research to measure the economic value of recreational resources [48] and that there are no right or wrong answers.

The first section dealt with respondents' socio-demographic data, including gender, age, marital status, household size, level of education, occupation, monthly income, purpose of visiting parks and the amount spent at a park during the last visit. Even though it was suggested by Mitchell and Carson [49] and followed by Piriyapada and Wang [44] to put contingent valuation questions related to personal status at the end of the survey, we decided to place them at the beginning due to the assertive attitude of Croats towards revealing personal income and expenditure information, as well as inexperience in CVM surveys in general. Therefore, general questions were asked at the beginning to relax respondents, whereas income, expenditure and WTP questions were introduced at the end.

The second section was related to the status and environmental concerns over the current landfill site. The respondents were asked about the distance from home to the landfill, the issues that concern them most with respect to the landfill, desirable conversions, perceived experience with respect to the status of the area around the landfill (displayed with pictures in color), perceived experience with respect to conversion of the landfill to recreational park (displayed with pictures in color) and about decisions on visiting the park in the future or not based on their perceived level of satisfaction.

The third section contained the question about WTP and reasons for not willing to pay if a respondent answered "no" to both bids. The respondents were asked two questions to elicit the maximum amount they would be willing to pay as an entrance fee on visitation. Before the question about WTP was posed, a short introduction on the future recreational park's expenditures was given. 
The respondent was asked if he would be willing to pay a specific amount, randomly chosen from five starting bid amounts (The amounts were in Kuna (HRK or kn) because the Euro has not been introduced in Croatia yet. The exchange rate between Kuna and the Euro was 7.45 at the moment of conducting the survey), followed by the second bid offered, that was half (if the answer was "no") or double (if the answer was "yes") of the starting bid, accordingly (Table 1).

Table 1. The sets of the double bounded questions.

\begin{tabular}{cccc}
\hline \multicolumn{2}{c}{ Initial BID } & Second BID (Upper) & Second BID (Lower) \\
\hline $10.00 \mathrm{HRK}$ & $€ 1.34$ & $€ 2.68$ & $€ 0.67$ \\
$20.00 \mathrm{HRK}$ & $€ 2.68$ & $€ 5.36$ & $€ 1.34$ \\
$30.00 \mathrm{HRK}$ & $€ 4.03$ & $€ 8.06$ & $€ 2.02$ \\
$50.00 \mathrm{HRK}$ & $€ 6.71$ & $€ 13.42$ & $€ 3.36$ \\
$100.00 \mathrm{HRK}$ & $€ 13.42$ & $€ 26.84$ & $€ 6.71$ \\
\hline
\end{tabular}

Starting bids were developed in accordance with the field survey responses. The respondents were asked about the amount they are willing to pay for a future park. To obtain as realistic responses as possible, they were informed about average monthly expenses for a citizen of the city of Zagreb-electricity HRK 200.00 (€26.84), water HRK 150.00 (€20.13), heating HRK 250.00 (€33.55), municipal waste collection HRK 40.00 (€5.40). Other questions were introduced in order to test respondents' honest responses to the WTP questions, such as "what is your monthly personal income (after tax); "state the amount spent during your last visit to a recreational park"; "how often do you visit recreational parks in Zagreb"; "according to your perceived level of satisfaction, would you visit recreational parks in the future."

Considering the fact that the future park does not exist yet, nor did the public have any idea about it before conducting this survey, the entire scenario was hypothetical and therefore the CVM was employed as one of the standard methods to measure the economic values of nonmarket goods such as recreational resources $[39,48,50]$.

Since the current landfill presents enormous problems to citizens, particularly due to discontent caused by odor, concern about impact on health and general mistrust of the government [26], a high response rate $(97.70 \%$ ) should not be surprising (only 9 of 391 randomly selected respondents refused to take part in the survey after being acquainted with the purpose of surveying). The survey was translated into the local language (Croatian) by a professional bilingual translator, whose mother tongue was Croatian and given to 20 random respondents to check if everything was fully clear.

\subsection{Sampling}

According to the 2011 census, the population of the city of Zagreb is 790,017, distributed over 17 districts. Prior to the final survey, in December 2016 a pretest was administered to determine bid sets [51]. After presenting the survey form to 20 respondents, few adjustments in content were applied and the final version was established. Even though we started in December 2016 to use the positive Christmas atmosphere and respondents' willingness to participate in the survey, the main sampling took place during February 2017. The sample was divided into three zones [51] based on the distance range of respondents' home from the current landfill to decrease the sample error and the survey was then conducted accordingly-(1) less than one kilometer ( $14 \%$ of respondents); (2) one to two kilometers (17\% of respondents); more than three kilometers (69\% of respondents). The number of residents targeted in each zone was proportional to the actual population in these areas. As recommended by Xu et al. [52], in-person interviews were administered to randomly selected respondents within three zones as misunderstandings can be resolved at once in this format. In total, four interviewers participated over a two-year period. To ensure the quality of sampling, each interviewer was accompanied by one of the authors during their first day of interviewing. The average duration of interviews was 11 minutes. The interview started with the survey's content and purpose 
explanation and information about the intention of compensating respondents' time in the form of small gifts (local sweets), which were presented at the end [44]. The survey was conducted as follows - throughout the day in zone 1; from 9 a.m. until 4 p.m. in zone 2; and after 5 p.m. in zone Figure 3.

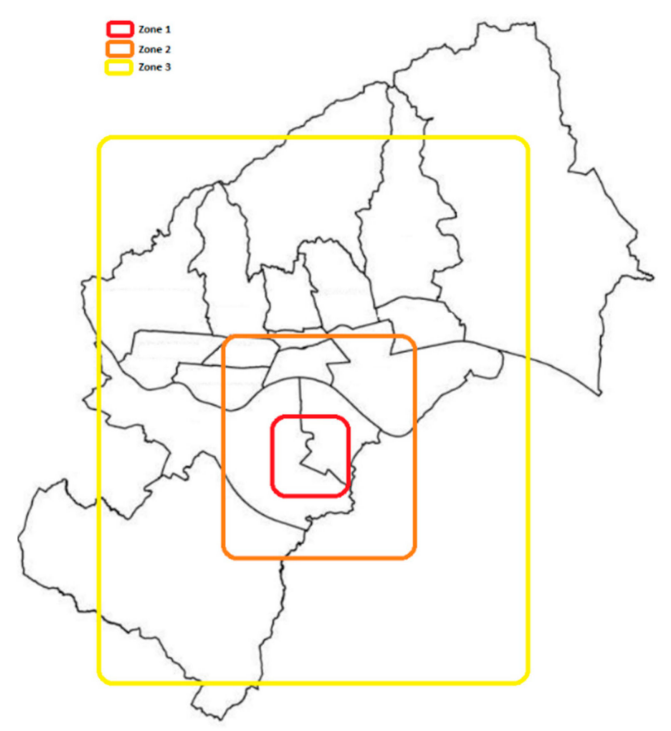

Figure 3. Sampling zones. Source: Department of Statistics of the City of Zagreb, 2011. http://www1.zagreb.hr/zgstat/documents/POPIS\%202011/GZ_stanovnistvo_kucanstva_stanovi/ Popis2011_StanovniciKucanstvaStanovi_GradZagreb.pdf.

\subsection{Contingent Valuation}

This study uses the broadly-applied contingent valuation method to asses an individual's willingness to pay for an entry fee to a future recreational park, which we suggest to build on top of the Jakuševec landfill in Zagreb, Croatia after its closure. As explained by Loomis [53], the CVM is a survey technique that constructs a hypothetical market to measure WTP for different levels of non-marketed natural and environmental resources. The questionnaire was prudently designed, having in mind the local peoples' unfamiliarity with CVM survey and their aversion towards interviewing and paying entrance fees to recreational sites. Therefore, respondents were provided with details about the organizer, interviewer, nature and purpose of the hypothetical market situation [48,51].

In general, CVM, including DCCVM, is subject to various biases-(i) design bias due to subjectivity in the starting bids or payment vehicles [54]; (ii) respondents' psychological conditions leading to anchoring and yea-saying biases [55]; (iii) hypothetical bias causing higher WTP [56]; (iv) operational bias due to unfamiliarity with the good to be valued [57]. The approach itself is not difficult to perceive because it is comparable to the usual market transactions consumers are facing [58].

\subsection{WTP Econometric Model}

The DCCVM questionnaire was employed to elicit respondents' WTP [51] for a future park built on the land of the current landfill. For the referendum question format, respondents can accept or reject (bid) amounts proposed, which is more likely to estimate maximum WTP than an open-ended WTP question format [52,59]. To obtain more information for the WTP estimates, the "follow up" or double bounded (DB) question was presented in addition to single bounded (SB) questions [60], lower if the initial bid price was accepted and higher if it was rejected. Haab and McConnell [59] hold that there are three ways in which DB DC models increase efficiency over SB DC models-(1) clear bounds on WTP in case of yes-no or no-yes responses; (2) efficiency gains for the no-no pairs and yes-yes 
pairs because they truncate the distributions where the respondent's WTP can lie; (3) the number of responses is increased, so that a given function is fitted with more observations.

The probability $\left(\mathrm{Prob}_{i}\right)$ of a respondent to answer "yes," that is, the probability that the respondent thinks that he is better off in the proposed scenario, even with the required payment and the probability to answer "no" are as follows:

$$
\begin{gathered}
\operatorname{Prob}_{i}^{\text {yes }}=\pi^{y}=1-G(B I D ; \theta), \\
\operatorname{Prob}_{i}^{n o}=\pi^{n}=G(B I D ; \theta),
\end{gathered}
$$

where $G(B I D ; \theta)$ is a statistical distribution function with parameter vector $\theta$ and BID is a bid offer, which can be estimated using the logit regression model. Following Asafu-Adjaye and Tapsuwan [58], the logit model can be expressed as the logistic cumulative density function

$$
G(B I D ; \theta)=\frac{1}{\left[1+e^{a-b(B I D)}\right]},
$$

where $\theta \equiv(a, b)$ and $\mathrm{a}$ and $\mathrm{b}$ are the intercept and slope coefficients to be estimated, respectively. $G(B I D ; \theta)$ is the cumulative density function of the individual's true maximum WTP. Respondents will accept a suggested entrance fee (BID) for recreational activities in the future park to maximize their utility under the following condition:

$$
v(1, Y-B I D ; S ; C)+\varepsilon_{1} \geq v(0, Y ; S ; C)+\varepsilon_{0}
$$

and refuse it if otherwise [61]. Here, $v$ is the indirect utility function, $Y$ is income (monthly after tax), BID is a bid offer, $S$ stands for other socio-economic characteristics affecting individual preference, $C$ represents environmental concerns about the current site and $\varepsilon_{1}$ and $\varepsilon_{0}$ are the identically, independently distributed (i.i.d.) random variables with zero means.

The utility difference between "yes" and "no" $(\Delta \eta)$ can be described as

$$
\Delta \eta=v(1, Y-B I D ; S ; C)-v(0, Y ; S ; C)+\left(\varepsilon_{1}-\varepsilon_{0}\right)
$$

Following Hanemann's logit model [61], the dependent variable (the answer to WTP question) is binary, coded with a value of 1 if affirmative and 0 otherwise, the explanatory variables are a constant and the bid is proposed. The model is estimated by maximum likelihood because the ML estimators have better properties when the dependent variable is categorical [62]. The probability that a respondent will accept a bid offer can be expressed in the logistic form as

$$
P_{i}^{y e s}=F \eta \Delta v=(1+\exp -\Delta v)^{-1}=\frac{1}{1+e^{-\left(\alpha+\beta_{1} B I D+\beta_{2} S+\beta_{2} C\right)}}
$$

where $F \eta$ is a cumulative distribution function, $\alpha$ is the intercept and $\beta_{i}$ is the coefficients of the bid (BID), socio-economic variables (S) and concerns about the current site (C), respectively.

As Hanemann demonstrated, the mean WTP can be obtained by using the following expression:

$$
W T P_{\text {mean }}=\ln \left(1+e^{\alpha^{*}}\right) / \beta,
$$

where $\alpha^{*}$ is the adjusted intercept and $\beta$ is the slope coefficient.

According to Hanemann, Loomis and Kanninen [63], the log-likelihood function for all respondents is

$$
\begin{gathered}
\ln L^{s}(\theta)=\sum_{i=1}^{N}\left\{d_{i}^{y} \ln \pi^{y}\left(B I D_{i}\right)+d_{i}^{n} \ln \pi^{n}\left(B I D_{i}\right)\right\} \\
\left.\left.G\left(B I D_{i} ; \theta\right)\right]+d_{i}^{n} \ln G\left(B I D_{i} ; \theta\right)\right\},
\end{gathered}
$$


where $d_{i}^{y}$ is equal to one if the $i$ th response is "yes" and zero otherwise and $d_{i}^{n}$ is equal to one if the $i$ th response is "no" and zero otherwise.

We used DB DCCVM in this study and respondents were presented with two bid prices. Therefore, there are four possible two-bid response sequences-yes-yes, no-no, no-yes and yes-no. The probability of a respondent to answer any of these outcomes is

$$
\begin{gathered}
P_{i}\left(\frac{\text { yes }}{y e s}\right)=\pi_{i}^{y y}=1-G_{C}\left(B I D_{U}\right), \\
P_{i}\left(\frac{n o}{n o}\right)=\pi_{i}^{n n}=G_{C}\left(B I D_{L}\right), \\
P_{i}\left(\frac{n o}{y e s}\right)=\pi_{i}^{n y}=G_{C}(B I D)-G_{C}-\left(B I D_{L}\right), \\
P_{i}\left(\frac{\text { yes }}{n o}\right)=\pi_{i}^{y n}=G_{C}\left(B I D_{U}\right)-G_{C}-(B I D),
\end{gathered}
$$

and the log-likelihood function for the double-bounded model is

$$
\ln L^{s}(\theta)=\left[d_{i}^{y y} \ln \pi_{i}^{y y}+d_{i}^{n n} \ln \pi_{i}^{n n}+d_{i}^{n y} \ln \pi_{i}^{n y}+d_{i}^{y n} \ln \pi_{i}^{y n}\right],
$$

where $d_{i}^{y y}, d_{i}^{n n}, d_{i}^{n y}$ and $d_{i}^{y n}$ are equal to one when a set of responses is one of the possible outcomes and zero if otherwise.

\section{Model Specification}

If the dependent variable (WTP) is influenced by independent variables, including individuals' socio-economic characteristics and concerns connected with the site, the WTP function can be derived as

$$
Y_{i}=f(B I D, G E N, A G E, E D U, I N C O M E, D E C I S I O N, \text { DISTANCE, CONVERSION), }
$$

where $Y_{i}$ is a binary variable, representing the respondent's WTP; BID is a bid offer (offered in the Croatian currency Kuna and for the sake of the analysis transformed into the Euro); socio-economic variables-gender (GENDER), age (AGE), education (EDU), personal income after tax on an annual basis (INCOME) and whether or not the respondent is the decision-maker about expenses within the family (DECISION); variables related to respondents' concerns about the landfill site-distance from the site (DISTANCE) and perceived experience with respect to the conversion of the landfill to a recreational park (CONVERSION) as defined in Table 2.

Table 2. Dichotomous Choice Contingent Valuation Method Variable Definitions.

\begin{tabular}{cc}
\hline Variable Name & Definition \\
WTP & $\begin{array}{r}\text { Dependent variable, takes the value } 1 \text { if the respondent is willing to pay the proposed bid } \\
\text { amount, } 0 \text { if the respondent refuses to pay }\end{array}$ \\
BID & $\begin{array}{c}\text { Hypothetical amounts of the entrance fee for visiting a future recreation park, proposed to } \\
\text { every respondent } \\
\text { Socio-economic }\end{array}$ \\
GEN & $\begin{array}{c}\text { Gender, } 1 \text { if the respondent is male, } 0 \text { otherwise } \\
\text { AGE }\end{array}$ \\
EDU & $\begin{array}{c}\text { Level of education (in years of schooling) } \\
\text { Average annual income after tax in '000 (€) }\end{array}$ \\
DECISION & Decision-maker about expenses within family, 1 if it is the respondent, 0 otherwise \\
Concerns about the site & Distance from the site (1 if up to $1 \mathrm{~km}, 2$ if $1-3 \mathrm{~km}, 3$ if more than $3 \mathrm{~km})$ \\
DISTANCE & $\begin{array}{c}\text { Perceived experience with respect to conversion of the landfill to a recreational park, } 1 \text { for } \\
\text { "FONVERSION }\end{array}$ \\
\hline
\end{tabular}




\section{Results and Discussion}

Two statistical models were estimated, single bounded and double bounded DCCVMs, yet this study is more interested into capturing the WTP after the "follow up" question. The SB model was estimated for the purpose of comparison. Descriptive statistics for the variables used in the regression analysis are presented in Table 3.

Table 3. Descriptive Statistics.

\begin{tabular}{ccc}
\hline Variable & Mean & Std. Deviation \\
\hline GENDER & 0.330 & 0.472 \\
AGE & 2.000 & 0.758 \\
EDU & 15.380 & 2.226 \\
INCOME & 10.800 & 5.528 \\
DECISION & 0.700 & 0.460 \\
DISTANCE & 2.570 & 0.705 \\
\hline
\end{tabular}

The final sample was 382 responds by the citizens of Zagreb. The distribution of the WTP in DB DCCVM is provided in Table 4. As expected, the probability of accepting a bid declines with an increase in the bid level.

Table 4. Frequency of WTP in DB DCCVM.

\begin{tabular}{|c|c|c|c|c|c|c|c|c|}
\hline \multicolumn{2}{|c|}{ Initial BID } & \multirow{2}{*}{$\begin{array}{c}\begin{array}{c}\text { Second BID } \\
\text { (upper) }\end{array} \\
\qquad € 2.68\end{array}$} & \multirow{2}{*}{$\begin{array}{c}\begin{array}{c}\text { Second BID } \\
\text { (lower) }\end{array} \\
\qquad € 0.67\end{array}$} & \multirow{2}{*}{$\begin{array}{c}\begin{array}{c}\text { yes/yes } \\
(\%)\end{array} \\
\begin{array}{c}9.69 \% \\
37\end{array}\end{array}$} & \multirow{2}{*}{$\begin{array}{c}\begin{array}{c}\text { yes/no } \\
(\%)\end{array} \\
3.66 \% \\
14\end{array}$} & \multirow{2}{*}{$\begin{array}{c}\begin{array}{c}\text { no/yes } \\
(\%)\end{array} \\
2.36 \% \\
9\end{array}$} & \multirow{2}{*}{$\begin{array}{c}\begin{array}{c}\text { no/no } \\
(\%)\end{array} \\
1.31 \% \\
5\end{array}$} & \multirow{2}{*}{$\begin{array}{c}\text { Total } \\
\text { Respondents } \\
17.02 \% \\
65\end{array}$} \\
\hline $10.00 \mathrm{HRK}$ & $€ 1.34$ & & & & & & & \\
\hline 20.00 HRK & $€ 2.68$ & $€ 5.36$ & $€ 1.34$ & $\begin{array}{c}6.28 \% \\
24\end{array}$ & $\begin{array}{c}5.76 \% \\
22\end{array}$ & $\begin{array}{c}2.62 \% \\
10\end{array}$ & $\begin{array}{c}4.71 \% \\
18\end{array}$ & $\begin{array}{c}19.37 \% \\
74\end{array}$ \\
\hline $50.00 \mathrm{HRK}$ & $€ 6.71$ & $€ 13.42$ & $€ 3.36$ & $\begin{array}{c}2.09 \% \\
8\end{array}$ & $\begin{array}{c}4.19 \% \\
16\end{array}$ & $\begin{array}{c}4.19 \% \\
16\end{array}$ & $\begin{array}{c}4.97 \% \\
19\end{array}$ & $\begin{array}{c}15.45 \% \\
59\end{array}$ \\
\hline 100.00 HRK & $€ 13.42$ & $€ 26.84$ & $€ 6.71$ & $\begin{array}{c}0.79 \% \\
3\end{array}$ & $\begin{array}{c}6.81 \% \\
26\end{array}$ & $\begin{array}{c}6.81 \% \\
26\end{array}$ & $\begin{array}{c}11.78 \% \\
45\end{array}$ & $\begin{array}{c}26.18 \% \\
100\end{array}$ \\
\hline
\end{tabular}

Note: "upper" refers to the amount double the initial BID, whereas "lower" refers to the amount twice the initial BID.

There are various motives which can influence respondents' non-willingness to pay, such as inexperience in answering such questions or the unacceptance of the monetary valuation of natural goods [64-66]. In this study, respondents were asked to state the reason for refusing to pay. Out of 382 respondents, 111 answered no-no to the WTP questions ( $29 \%$ ). The reasons are as follows- $46 \%$ say that it is the responsibility of the city government; $13 \%$ cannot afford any additional expense; $11 \%$ of them do not believe their money would be spent as claimed; $8 \%$ think that businesses at the future site should support the investment, not individuals; $4 \%$ is concerned where the waste will be disposed if the landfill is gone; and $18 \%$ of the respondents recognized the bid offer as too high, so they suggested a lower amount that they would be willing to pay or claimed that entrance to public parks should not be charged at all. We decided to exclude all zero bidders following other authors [38,58], because they can introduce bias for the valuation, despite the fact that most of the respondents are potentially active users of the future park as only 14 of them $(3.66 \%)$, according to their perceived level of satisfaction, have no plans to visit recreational parks in the future.

The maximum likelihood estimates in the linear DB functional form are presented in Table 5. The bid offer variable coefficients are negative as expected and statistically significant $(p<0.01)$ across both models [42]. This indicates that the probability of the "yes" response decreases (increases) as 
the bid offer increases (decreases) under the hypothetical market scenario. Table 5 shows that the GEN variable is positive and significant $(p<0.05)$, which implies that males are more likely to pay an entrance fee to a new recreation park. This result is consistent with other studies $[27,28,67,68]$. Typically, women have more "sensitive" perceptions of the surrounding landscape [69] while men prefer well-controlled scenery [70-73]. The current study results could relate to the latter supposing that men perceive the proposed conversion of an old landfill into a recreational park as moving towards improved management. Women are keener on romantic gardens [74]. The AGE variable shows the expected positive sign and significant $(p<0.1)$, implying that probability of WTP for the proposed entrance fee increases with the increase in age. The coefficient on EDU has negative sign $[27,75,76]$, suggesting that the WTP does not increase with the years of schooling. Some findings suggest that the correlation between WTP and EDU is secondary to the correlation of WTP and INCOME or expenditure [76]. The reason why respondents with better education are not willing to pay more may be the lack of specific knowledge on environmental issues [27,69]. INCOME shows a positive influence on the dependent variable, indicating that wealthier respondents would be willing to pay more. The estimated coefficient of DISTANCE was found positive, unlike other examples [43], which could be explained by the fact that the citizens living within a kilometer from the current landfill receive a substantial amount of money as a certain compensation, therefore they are not highly motivated to support its closure. DECISION is negative in the DB model, indicating that those who are not decision-makers on a family budget would be willing to pay an entrance fee. CONVERSION variable is positive and significant $(p<0.05)$, implying that those respondents whose perceived experience with respect to conversion of the landfill to a recreational park is unobstructed are more likely to pay.

Table 5. Maximum Likelihood Estimates for DB DCCVM.

\begin{tabular}{ccccccc}
\hline \multicolumn{7}{c}{ Binary Logistic Regression; Dependent Variable $=$ WTP (y/n); DB DCCVM } \\
\hline & B & S.E. & Wald & df & Sig. & Exp(B) \\
\hline BID2 & -0.196 & 0.032 & 37.777 & 1.000 & 0.000 & 0.822 \\
GEN & 0.794 & 0.332 & 5.700 & 1.000 & 0.017 & 2.212 \\
AGE & 0.348 & 0.209 & 2.770 & 1.000 & 0.096 & 1.416 \\
EDU & -0.073 & 0.076 & 0.925 & 1.000 & 0.336 & 0.930 \\
INCOME & 0.025 & 0.032 & 0.612 & 1.000 & 0.434 & 1.026 \\
DECISION & -0.707 & 0.344 & 4.224 & 1.000 & 0.040 & 0.493 \\
DISTANCE & 0.022 & 0.221 & 0.010 & 1.000 & 0.920 & 1.023 \\
CONVERSION & 0.303 & 0.159 & 3.615 & 1.000 & 0.057 & 1.353 \\
Constant & 1.656 & 1.298 & 1.628 & 1.000 & 0.202 & 5.237 \\
N & 271 & & & & & \\
-2 Log likelihood & 276.850 & & & & & \\
Cox \& Snell R Square & 0.269 & & & & & \\
Nagelkerke R Square & 0.365 & & & & & \\
Hosmer \& Lemeshow Test & $X^{2}=5.248$ & Df $=8$ & $P=0.731$ & & & \\
Overall Predictive Accuracy (FCCC) & 77.5 & & & & & \\
\hline
\end{tabular}

We use the fully correctly classified cases (FCCC) method to evaluate the goodness-of-fit for the DB model as recommended by Kanninen and Khawaja [77]. The logit model has an overall predictive accuracy of $77.5 \%$ for the DB model and $72.3 \%$ for the SB model. The Hosmer and Lemeshow test of goodness-of-fit suggests that both models are a good fit to the data as $p=0.731$ and $p=0.453$ (>0.05) for the DB and the SB model, respectively. The determinants explained $36.5 \%$ and $10.8 \%$ of the variance of the WTP for DB and SB, respectively. Table 5 outlines the results of the logit model.

According to Hanemann et al. [63], the follow-up question can solve the problem of biases, including starting point bias, anchoring effects and yea-saying, that is that the DB DCCVM has an advantage over the SB model because the higher (lower) bid will help to recoup against too low (high) a choice of the initial bid and this study's results are in accordance with it. The mean WTP was calculated 
using Equation (7). The average WTP for the SB model is $€ 4.65$ (HRK34.64) per person, which is 1.28 times higher than the average WTP for the DB model, which equals $€ 3.63$ (HRK27.04) per person. To calculate the aggregate benefit of a future recreational park atop the current Jakuševec landfill in Zagreb, we used the estimated WTP from the DB model as a lower bound estimate and that of the SB model as an upper bound estimate. To measure the total number of park visitors on an annual basis, we multiplied the population of the city of Zagreb by the mean WTP for DB DCCVM of $€ 3.63$, which results in a lower bound estimate of $€ 2,867,762$. Similarly, using the mean WTP for SB model of $€ 4.65$, we obtain an upper bound estimate of $€ 3,673,579$ per annum. Assuming that $71 \%$ of the respondents would be willing to pay an entrance fee, the aggregate WTP benefits are estimated to be between $€ 2,036,111$ and $€ 2,608,241$ per year.

\section{Summary and Conclusions}

Waste management sites such as landfills, decommissioned animal feedlots, and manufacturing plants constitute a challenging problem faced by city management, especially for regions and locations which have limited land areas to be utilized for such a purpose. The challenges not only come from the constraints of the land space used for waste disposal but also from finding proper reuses of the land after it becomes decommissioned. The current literature has shown that there are various methods of land reuse including deep burying, incineration, land reconstruction, and others. However, to find out the best land use alternatives, it is crucial for the decision makers to assess the economic value to be potentially accrued either by the recovered resources or by the potential consumers who are directly affected by the land recovery strategies to ensure an efficient utilization of land recovery. Nevertheless, valuing reused land remains complex due to its nature, in which the market price for alternative land reuses is generally not available.

In this study, we attempted to value a prospective city recreational park to be built on a decommissioned landfill area. In the process, the contingent valuation method (CVM) was used for the entire analysis, in which a double-bounded dichotomous choice approach was used for survey and questionnaire designs, and the logit model was utilized for parameter estimation. The results show that people are willing to pay HRK27.04 (€3.63) per person per year for the proposed park facility. Considering that there are nearly 1 million citizens in the city of Zagreb, that could be translated into a total of HRK21,364,827 ( $€ 2,867,762)$ of annual park revenue that could be collected solely from the park's entrance fees. According to a municipal government official, this annual revenue being collected from the park admission tickets is able to cover the park's annual operating costs, which are estimated to be roughly below $€ 2,000,000$. The findings of this study have to be regarded in light of a few limitations. First, we understand that our estimated economic value result is very conservative if not extremely so, owing to the fact that 30 percent of survey participants responded a zero amount of WTP. However, this does not mean the true economic value to those respondents is zero-with the use of face-to-face conversations with the respondents, we got the clear impression that a large part of the null-responses was due to their antipathy over the tax payment levied by the government, which means the real economic value being accrued by those respondents must be greater than zero. The second limitation concerns the sample size. Although we added new data to verify the accuracy of the estimates of WTP, a bigger sample size could lead to more accurate results. The third limitation is a lack of understanding of the specific environmental issue by the respondents. Notwithstanding that we devoted 11 minutes on average for each respondent, it may not have been sufficient for them to grasp the environmental issue completely. Also, there is a lack of prior research studies on the topic in Croatia. As we based our research on peoples' perceptions, we conclude that better results could be obtained if respondents would have more experience with this type of method. This study confirms the findings in CVM related to the motivations behind zero WTP. Protest bidders are motivated by moral reasons [78] rather than a lack of understanding. This study finds that males are more likely to pay an entrance fee, which is generally not the case when it comes to environmental issues [69]. 
Our findings support the idea that environmental education, policy, and practice should be more feminist-oriented to equalize the gender imbalance in the levels of scientific knowledge [79,80].

The forgoing findings lead us to provide the following conclusions and policy suggestions for this potential land use transformation from landfill to a city recreational park in the city of Zagreb-first, converting the waste landfill site to a recreational park perhaps is one of the best choices. This is aligned with the Spatial Plan of the City of Zagreb and the concept Zagreb on Sava (Zagreb na Savi Program for Protection, Decoration and Use of the Sava River from the border with the Republic of Slovenia to Sisak City. For more information, visit www.zagrebnasavi.hr.), which aims at redesigning the Sava river banks to be stretched from Slovenia to Sisak (Croatia) in order to best serve citizens' recreational and leisure activities. Thus, it is foreseeable that the strategy of ceasing the current landfill operations and converting it into a recreational park in Zagreb seems to fit the city's overall landscape design. Second, besides trees, flowers, and other types of fauna and flora, it may be beneficial to add more products and services to the park including a theme park, zoos, graffiti, swings, tree-lined paths, or BMX tracks [81,82]. Last but not least, our study should be considered as the first stage of an overall benefit-cost analysis for the project; further studies are necessary in order to derive more accurate estimates on the economic value to be accrued by the proposed city park. For instance (1) the effect on the real estate markets including housing demand, and realtor prices as a result of replacing the landfill with a recreational park; and (2) detailed field studies are also encouraged for justifying the construction of a public park from an ex-landfill in terms of the total environmental costs saved from the current landfill usage, and other benefits such as human health improvement.

Author Contributions: Conceptualization, M.O.; Methodology, M.O.; Writing—original draft preparation, M.O.; Writing-review and editing, E.W.; Supervision, E.W.; Funding acquisition, E.W.

Funding: This work was supported by the National Natural Science Foundation of China, Grant No. 71640035.

Acknowledgments: We would like to thank respondents who showed interest in our research and interviewers who patiently filled out surveys. We thank employees of ZGOS, Ministry of Environment and Energy and Croatian Environment Agency for generously providing requested data.

Conflicts of Interest: The authors declare no conflict of interest.

\section{References}

1. Kumar, S.; Smith, S.R.; Fowler, G.; Velis, C.; Kumar, S.J.; Arya, S.; Rena Kumar, R.; Cheeseman, C. Challenges and opportunities associated with waste management in India. R. Soc. Open Sci. 2017, 4, 160764. Available online: https://www.ncbi.nlm.nih.gov/pubmed/28405362 (accessed on 25 October 2019). [CrossRef] [PubMed]

2. Wanwari, S.; Thakur, I.; Vijay, V.K.; Ghosh, P. Scenario of Landfilling in India: Problems, Challenges, and Recommendations. In Handbook of Environmental Materials Management; Springer: Basel, Switzerland, 2018.

3. Gerth, A.; Hebner, A.; Kopielski, K.; Schneider, P.; Le Hung, A. Reuse of a closed landfill site for installation and operation of a biomass utilization plant. In Proceedings of the International Conference on Advanced Technology and Sustainable Development, International Symposium on Green Technology, Kaohsiung, Taiwan, 24-25 November 2016.

4. Fernando, R.L.S. Solid waste management of local governments in the Western Province of Sri Lanka: An implementation analysis. Waste Manag. 2019, 84, 194-203. Available online: https://www.sciencedirect. com/science/article/pii/S0956053X18307086 (accessed on 25 October 2019). [CrossRef] [PubMed]

5. Zaman, A.; Lehmann, S. Challenges and Opportunities in Transforming a City into a "Zero Waste City". Challenge 2011, 2, 73-93. [CrossRef]

6. Nelles, M.; Grünes, J.; Morscheck, G. Waste Management in Germany-Development to a Sustainable Circular Economy? Procedia Environ. Sci. 2016, 35, 6-14. [CrossRef]

7. Singh, R.; Yabar, H.; Nozaki, N.; Rakwal, R. Analyzing Waste Problems in Developing Countries: Lessons for Kathmandu, Nepal through Analysis of the Waste System in Tsukuba City, Japan. J. Sci. Res. Rep. 2015, 8, 1-13. [CrossRef] 
8. Rasmeni, Z.Z.; Madyira, D.M. A Review of the Current Municipal Solid Waste Management Practices in Johannesburg City Townships. Procedia Manuf. 2019, 35, 1025-1031. Available online: https://www. sciencedirect.com/science/article/pii/S2351978919307772 (accessed on 25 October 2019). [CrossRef]

9. Mat, S.; Kolokotsa, D. Urban Climate Mitigation Techniques, 1st ed.; Routledge: London, UK, 2016; p. 222.

10. Chiesura, A. The role of urban parks for the sustainable city. Landsc. Urban Plan. 2004, 68, 129-138. [CrossRef]

11. Hajmirsadeghi, R.S. The influence of urban parks on sustainable city via increase quality of life. Elixir Sustain. Archit. 2012, 51, 10766-10770.

12. Hartig, T.; Mang, M.; Evans, G.W. Restorative effects of natural environment experience. Environ. Behav. 1991, 23, 3-26. [CrossRef]

13. Maas, J.; van Dillen, S.M.E.; Verheij, R.A.; Groenewegen, P.P. Social contacts as a possible mechanism behind the relation between green space and health. Health Place 2009, 15, 586-595. [CrossRef]

14. Ward Thompson, C.; Roe, J.; Aspinall, P.; Mitchell, R.; Clow, A.; Miller, D. More green space is linked to less stress in deprived communities: Evidence from salivary cortisol patterns. Landsc. Urban Plan. 2012, 105, 221-229. [CrossRef]

15. Engström, G.; Gren, A. Capturing the value of green space in urban parks in a sustainable urban planning and design context: Pros and cons of hedonic pricing. Ecol. Soc. 2017, 22, 21. [CrossRef]

16. James, P.; Tzoulas, K.; Adams, M.D.; Barber, A.; Box, J.; Breuste, J.; Elmqvist, T.; Frith, M.; Gordon, C.; Greening, K.L.; et al. Towards an integrated understanding of green space in the European built environment. Urban For. Urban Green. 2009, 8, 65-75. [CrossRef]

17. Majumdar, S.; Deng, J.; Zhang, Y.; Pierskalla, C. Using contingent valuation to estimate the willingness of tourists to pay for urban forests: A study in Savannah, Georgia. Urban For. Urban Green. 2011, 10, 275-280. [CrossRef]

18. Tzoulas, K.; Korpela, K.; Venn, S.; Yli-Pelkonen, V.; Kaźmierczak, A.; Niemela, J.; James, P. Promoting ecosystem and human health in urban areas using Green Infrastructure: A literature review. Landsc. Urban Plan. 2007, 81, 167-178. [CrossRef]

19. Wolch, J.R.; Byrne, J.; Newell, J.P. Urban green space, public health, and environmental justice: The challenge of making cities "just green enough". Landsc. Urban Plan. 2014, 125, 234-244. [CrossRef]

20. Bullock, C. Valuing Urban Green Space: Hypothetical Alternatives and the Status Quo. J. Environ. Plan. Manag. 2008, 51, 15-35. [CrossRef]

21. Coombes, E.; Jones, A.P.; Hillsdon, M. The relationship of physical activity and overweight to objectively measured green space accessibility and use. Soc. Sci. Med. 2010, 70, 816-822. [CrossRef]

22. Kuo, F.E.; Sullivan, W.C. Environment and Crime in the Inner City. Environ. Behav. 2001, 33, $343-367$. [CrossRef]

23. Mitchell, R. Is physical activity in natural environments better for mental health than physical activity in other environments? Soc. Sci. Med. 2013, 91, 130-134. [CrossRef]

24. Government of the Republic of Croatia. Waste Management Plan of the Republic of Croatia for the Period 2017-2022 2017. Available online: http://www.mzoip.hr/doc/management_plan_of_the_republic_of_croatia_ for_the_period_2017-2022.pdf (accessed on 22 May 2018).

25. Barcic, D.; Ivancic, V. Impact of the prudinec/jakusevec landfill on environment pollution. Šumarski List 2010, 134, 347-359.

26. Kountouris, Y.; Nakic, Z.; Sauer, J. Political instability and non-market valuation: Evidence from Croatia. Resour. Energy Econ. 2015, 41, 19-39. Available online: https://www.sciencedirect.com/science/article/pii/ S0928765515000196 (accessed on 20 May 2019). [CrossRef]

27. Togridou, A.; Hovardas, T.; Pantis, J.D. Determinants of visitors' willingness to pay for the National Marine Park of Zakynthos, Greece. Ecol. Econ. 2006, 60, 308-319. Available online: https://www.sciencedirect.com/ science/article/pii/S0921800906000024 (accessed on 8 October 2019). [CrossRef]

28. Mmopelwa, G.; Kgathi, D.L.; Molefhe, L. Tourists' perceptions and their willingness to pay for park fees: A case study of self-drive tourists and clients for mobile tour operators in Moremi Game Reserve, Botswana. Tour. Manag. 2007, 28, 1044-1056. Available online: https://www.sciencedirect.com/science/article/pii/ S0261517706001440 (accessed on 8 October 2019). [CrossRef]

29. Bouazza, A.; Kavajanzian, E.J. Construction on Former Landfills. In Proceedings of the 2nd ANZ Conference on Environmental Geotechnics, Newcastle, Australia, 28-30 November 2001; pp. 467-482. 
30. Wong, C.T.; Leung, M.K.; Wong, M.K.; Tang, W.C. Afteruse development of former landfill sites in Hong Kong. J. Rock Mech. Geotech. Eng. 2013, 5, 443-451. [CrossRef]

31. Wiley, J.B.; Asadi, B. Redevelopment potential of landfills. A case study of six New Jersey projects. WIT Trans. Ecol. Environ. 2002, 55, 41-55. Available online: http://www.scopus.com/inward/record.url?eid=2-s2.03543061710\&partnerID=tZOtx3y1 (accessed on 22 October 2019).

32. Perovic, S. Brownfield regeneration-Imperative for sustainable urban development. Građevinar 2012, 64, 373-383.

33. Glumac, B.; Herrera-Gomez, M.; Licheron, J. A hedonic urban land price index. Land Use Policy 2019, 81, 802-812. Available online: https://www.sciencedirect.com/science/article/pii/S0264837718304186 (accessed on 10 October 2019). [CrossRef]

34. Latinopoulos, D.; Mallios, Z.; Latinopoulos, P. Valuing the benefits of an urban park project: A contingent valuation study in Thessaloniki, Greece. Land Use Policy 2016, 55, 130-141. [CrossRef]

35. Lindsey, G.; Knaap, G. Willingness to Pay for Urban Greenway Projects. J. Am. Plan. Assoc. 1999, 65, $297-313$. [CrossRef]

36. Chen, W.Y.; Hua, J. Citizens' distrust of government and their protest responses in a contingent valuation study of urban heritage trees in Guangzhou, China. J. Environ. Manag. 2015, 155, 40-48. [CrossRef] [PubMed]

37. Cho, S.H.; Newman, D.H.; Bowker, J.M. Measuring rural homeowners' willingness to pay for land conservation easements. For. Policy Econ. 2005, 7, 757-770. [CrossRef]

38. Garcia-Llorente, M.; Martin-Lopez, B.; Montes, C. Exploring the motivations of protesters in contingent valuation: Insights for conservation policies. Environ. Sci. Policy 2011, 14, 76-88. Available online: http://www.sciencedirect. com/science/article/pii/S1462901110001590?via\%3Dihub (accessed on 5 June 2018). [CrossRef]

39. Loomis, J.; Helfand, G. Environmental policy analysis for decision making. Environ. Impact Assess. Rev. 2003, 22, 441.

40. Faizan, M.; Sasekumar, A.; Chenayah, S. Estimation of local tourists Willingness to Pay. Reg. Stud. Mar. Sci. 2016, 7, 142-149. [CrossRef]

41. Getzner, M.; Švajda, J. Preferences of tourists with regard to changes of the landscape of the Tatra National Park in Slovakia. Land Use Policy 2015, 48, 107-119. [CrossRef]

42. Iasha, A.; Yacob, M.R.; Kabir, I.; Radam, A. Estimating Economic Value for Potential Ecotourism Resources in Puncak Lawang Park, Agam District, West Sumatera, Indonesia. Procedia Environ. Sci. 2015, 30, 326-331. Available online: http://linkinghub.elsevier.com/retrieve/pii/S1878029615006520 (accessed on 8 June 2018). [CrossRef]

43. Olorunfemi, F.B. Willingness to Pay For Improved Environmental Quality among Residents Living in Close Proximity to Landfills in Lagos Metropolis, Nigeria. Afr. Res. Rev. 2009, 2, 27-33.

44. Piriyapada, S.; Wang, E. Modeling Willingness to Pay for Coastal Tourism Resource Protection in Ko Chang Marine National Park, Thailand. Asia Pac. J. Tour. Res. 2015, 20, 515-540. [CrossRef]

45. Wang, P.W.; Jia, J.B. Tourists' willingness to pay for biodiversity conservation and environment protection, Dalai Lake protected area: Implications for entrance fee and sustainable management. Ocean Coast. Manag. 2012, 62, 24-33. [CrossRef]

46. Pickering, C.; Rossi, S.D.; Hernando, A.; Barros, A. Current knowledge and future research directions for the monitoring and management of visitors in recreational and protected areas. J. Outdoor Recreat. Tour. 2018, 21, 10-18. [CrossRef]

47. Fundurulja, D.; Mužinić, M.; Pletikapić, Z. Odlagališta komunalnog otpada na području Hrvatske. Građevinar 2001, 52, 727-734. Available online: http://hrcak.srce.hr/index.php?show=clanak\&id_clanak_jezik=20001 (accessed on 5 June 2018).

48. Lee, C.-K. Valuation of nature-based tourism resources using dichotomous choice contingent valuation method. Tour. Manag. 1997, 18, 587-591. Available online: http://linkinghub.elsevier.com/retrieve/pii/ S0261517797000769 (accessed on 13 February 2018). [CrossRef]

49. Mitchell, R.C.; Carson, R.T. Using Surveys to Value Public Goods: The Contingent Valuation Method; Resources for the Future: Washington, DC, USA, 1989.

50. Hanemann, W.M. Valuing the Environment Through Contingent Valuation. J. Econ. Perspect. 1994, 8, 19-43. Available online: http://www.jstor.org/stable/2138337 (accessed on 13 February 2018). [CrossRef] 
51. Arrow, K.; Solow, R.; Portney, P.R.; Leamer, E.E.; Radner, R.; Schuman, H. Report of the NOAA Panel on Contingent Valuation. Fed. Regist. 1993, 58, 4601-4614. Available online: http://citeseerx.ist.psu.edu/ viewdoc/downloa (accessed on 12 December 2016).

52. Xu, Z.; Loomis, J.; Zhiqiang, Z.; Hamamura, K. Evaluating the performance of different willingness to pay question formats for valuing environmental restoration in rural China. Environ. Dev. Econ. 2006, 11, 585-601.

53. Loomis, J.B. Integrated Public Lands Management: Principles and Applications to National Forests, Parks, Wildlife Refuges, and BLM Lands. Second; Columbia University Press: New York, NY, USA, 2002.

54. Flachaire, E.; Hollard, G. Starting point bias and respondent uncertainty in dichotomous choice contingent valuation surveys. Resour. Energy Econ. 2007, 29, 183-194. [CrossRef]

55. Parumog, M.; Mizokami, S.; Kakimoto, R. Response Bias in Double Scenario Cvm Survey on Environmental Impacts of Road Projects *. 1998, pp. 1-4. Available online: https://www.jstage.jst.go.jp/article/journalip1984/ 21/0/21_0_265/_pdf (accessed on 28 October 2019).

56. Hausman, J. Contingent Valuation: From Dubious to Hopeless. J. Econ. Perspect 2012, 26, 43-56. [CrossRef]

57. Baral, N.; Stern, M.J.; Bhattarai, R. Contingent valuation of ecotourism in Annapurna conservation area, Nepal: Implications for sustainable park finance and local development. Ecol. Econ. 2008, 66, 218-227. [CrossRef]

58. Asafu-Adjaye, J.; Tapsuwan, S. A contingent valuation study of scuba diving benefits: Case study in Mu Ko Similan Marine National Park, Thailand. Tour. Manag. 2008, 29, 1122-1130. Available online: http://www.sciencedirect.com/science/article/pii/S0261517708000241?via\%3Dihub (accessed on 14 April 2017). [CrossRef]

59. Haab, T.C.; McConnell, K.E. Valuing Environmental and Natural Resources. Measurement 2002, 8, 326. Available online: http://www.sciencedirect.com/science/article/B6VP6-4FPJBC8-1/2/ 2873ac54e51f9e04d3e3e4d4d848bca4 (accessed on 14 April 2017).

60. Sarkhel, P.; Banerjee, S. Estimation of Average Willingness to Pay from Double Bounded Dichotomous Choice Data: Does the "Follow Up" matter? In Proceedings of the European Association Environmental Resource Economics 17th Annual Conference, Amsterdam, The Netherlands, 24-27 June 2009; pp. 1-20.

61. Hanemann, W.M. Welfare Evaluations in Contingent Valuation Experiments with Discrete Responses. Am. J. Agric. Econ. 1984, 66, 332-341. [CrossRef]

62. Bengochea-Morancho, A.; Fuertes-Eugenio, A.M.; del Saz-Salazar, S. A comparison of empirical models used to infer the willingness to pay in contingent valuation. Empir. Econ. 2005, 30, 235-244. [CrossRef]

63. Hanemann, M.; Loomis, J.; Kanninen, B. Statistical Efficiency of Double-Bounded Dichotomous Choice Contingent Valuation. Am. J. Agric. Econ. 1991, 73, 1255-1263. Available online: https://academic.oup.com/ ajae/article-lookup/doi/10.2307/1242453 (accessed on 3 May 2017). [CrossRef]

64. Mayor, K.; Scott, S.; Tol, R.S.J. Comparing the Travel Cost Method and the Contingent Valuation Method-An Application of Convergent Validity Theory to the Recreational Value of Irish Forests; ESRI working paper: Dublin, Ireland, 2007.

65. Bennett, J.; Morrison, M.; Blamey, R. Testing the validity of responses to contingent valuation questioning. Aust. J. Agric. Resour. Econ. 1998, 42, 131-148. [CrossRef]

66. Kosz, M. Valuing riverside wetlands: The case of the "Donau-Auen" national park. Ecol. Econ. 1996, 16, 109-127. Available online: http://linkinghub.elsevier.com/retrieve/pii/0921800995000585 (accessed on 9 March 2018). [CrossRef]

67. Duan, H.X.; Lü, Y.L.; Li, Y. Chinese public's willingness to pay for CO2 emissions reductions: A case study from four provinces/cities. Adv. Clim. Chang. Res. 2014, 5, 100-110. [CrossRef]

68. Li, Y.; Mu, X.; Schiller, A.; Zheng, B. Willingness to pay for climate change mitigation: Evidence from China. Energy J. 2016, 37, 179-194. [CrossRef]

69. Suchocka, M.; Jankowski, P.; Błaszczyk, M. Perception of urban trees by polish tree professionals vs. nonprofessionals. Sustainability 2019, 11, 211. [CrossRef]

70. Dunnett, N.; Qasim, M. Perceived benefits to human well-being of urban gardens. Horttechnology 2000, 10, 40-45. [CrossRef]

71. Bhatti, M.; Church, A. "I never promised you a rose garden": Gender, leisure and home-making. Leis. Stud. 2000, 19, 183-197. [CrossRef] 
72. Van den Berg, A.E.; van Winsum-Westra, M. Manicured, romantic, or wild? The relation between need for structure and preferences for garden styles. Urban For. Urban Green. 2010, 9, 179-186. Available online: https://www.sciencedirect.com/science/article/pii/S1618866710000105?via\%3Dihub (accessed on 9 October 2019). [CrossRef]

73. Zhao, J.; Xu, W.; Li, R. Visual preference of trees: The effects of tree attributes and seasons. Urban For. Urban Green. 2017, 25, 19-25. [CrossRef]

74. Vesely, É.-T. Green for green: The perceived value of a quantitative change in the urban tree estate of New Zealand. Ecol. Econ. 2007, 63, 605-615. Available online: https://www.sciencedirect.com/science/article/pii/ S0921800907000092 (accessed on 9 October 2019). [CrossRef]

75. Lee, J.S.; Mogasale, V.; Lim, J.K.; Carabali, M.; Sirivichayakul, C.; Anh, D.D.; Lee, K.S.; Thiem, V.D.; Limkittikul, K.; Velez, I.D.; et al. A multi-country study of the household willingness-to-pay for dengue vaccines: Household surveys in Vietnam, Thailand, and Colombia. PLoS Negl. Trop. Dis. 2015, 9, e0003810. [CrossRef] [PubMed]

76. David Mark, D.; Radermacher, R.; Koren, R. Willingness to pay for health insurance among rural and poor persons: Field evidence from seven micro health insurance units in India. Health Policy 2007, 82, $12-27$.

77. Kanninen, B.J.; Khawaja, M.S. Measuring Goodness of Fit for the Double-Bounded Logit Model: Reply. Am. J. Agric. Econ. 1995, 77, 885-890. [CrossRef]

78. Frey, U.J.; Pirscher, F. Distinguishing protest responses in contingent valuation: A conceptualization of motivations and attitudes behind them. PLOS ONE 2019, 14, e0209872. Available online: https: //www.ncbi.nlm.nih.gov/pubmed/30620731 (accessed on 22 October 2019). [CrossRef]

79. Bell, K. Bread and Roses: A Gender Perspective on Environmental Justice and Public Health. Int. J. Environ. Res. Public Health 2016, 13, 1005. Available online: https://www.ncbi.nlm.nih.gov/pubmed/27754351 (accessed on 23 October 2019). [CrossRef]

80. Hayes, B.C. Gender, Scientific Knowledge, and Attitudes toward the Environment: A Cross-National Analysis. Political Res. Q. 2001, 54, 657-671. Available online: http://www.jstor.org/stable/449275 (accessed on 23 October 2019). [CrossRef]

81. Veitch, J.; Salmon, J.; Deforche, B.; Ghekiere, A.; van Cauwenberg, J.; Bangay, S.; Timperio, A. Park attributes that encourage park visitation among adolescents: A conjoint analysis. Landsc. Urban Plan. 2017, 161, 52-58. [CrossRef]

82. Lindberg, M.; Schipperijn, J. Active use of urban park facilities-Expectations versus reality. Urban For. Urban Green. 2015, 14, 909-918. [CrossRef] 